\title{
Effect of Red tilapia (Oreochromis mossambicus $\times$ Oreochromis niloticus) on growth and survival of the pacific shrimp (Litopenaeus vannamei) in simultaneous polyculture under marine conditions
}

\author{
Efecto de la tilapia roja (Oreochromis mossambicus $\times$ Oreochromis niloticus) en el crecimiento y supervi- \\ vencia del camarón (Litopenaeus vannamei) en policultivo simultáneo bajo condiciones marinas
}

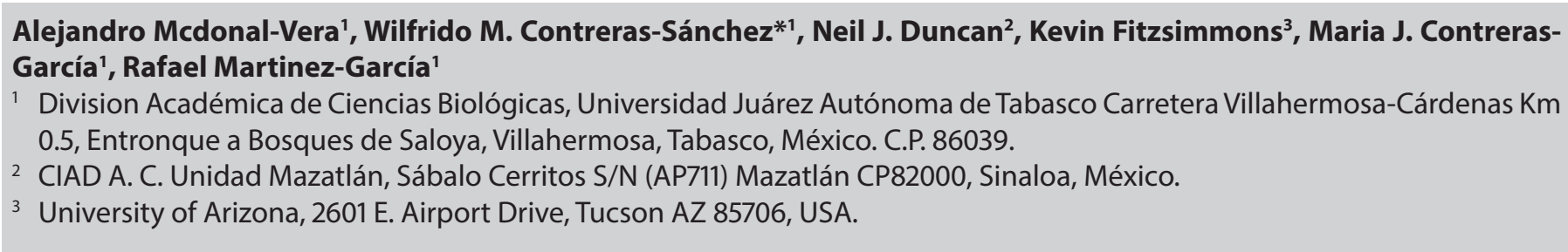

\section{ABSTRACT}

In the present investigation, we evaluated if the presence of tilapia affects growth and survival of shrimp during pre-growth and grow-out phases. In both experiments, we used a random-blocks design in a single earth pond ( $0.75 \mathrm{ha}$ ) that was prepared and divided into nine $(7 \times 30 \mathrm{~m})$ enclosures that were considered to be three blocks of three enclosures each. Each randomly stocked block consisted on Pacific white shrimp Litopenaeus vannamei (30 shrimp $/ \mathrm{m}^{2}$ ) and three different densities $\left(0.0,0.25\right.$ and $\left.0.50 \mathrm{fish} / \mathrm{m}^{2}\right)$ of red tilapia hybrids (Oreochromis mossambicus $x$ Oreochromis niloticus) to give three different treatments with three replicates. The results from the pre-growth and grow-out experiments followed the same trend. In both cases, we found no significant statistical differences $(P>0.05)$ in the final average weight of the shrimp. However, the experimental blocks had a significant $(P<0.05)$ effect on the mean sample weight of shrimp. Shrimp in blocks $B$ and $C$ were significantly bigger than shrimp from block $A(P<0.05)$. For both experiments, we found no effect of the presence of tilapias on survival or growth of shrimp. Keywords: Tilapia-shrimp polyculture, random block experiment, fish and crustaceans.

\section{RESUMEN}

Evaluamos si la presencia de tilapias libres afecta el crecimiento y la supervivencia de camarones en fase de preengorda y engorda. Para ambos experimentos, utilizamos un diseño de bloques al azar en un estanque rústico $(0.75$ ha) que fue preparado y dividido en nueve encierros ( 7 × 30 $\mathrm{m})$, se formaron tres bloques con tres encierros cada uno. Cada encierro dentro de cada bloque fue aleatoriamente seleccionado para sembrar camarón blanco del Pacífico, Litopenaeus vannamei (30 camarones $/ \mathrm{m}^{2}$ ) y tres diferentes densidades $\left(0.0,0.25\right.$ y 0.50 peces $\left./ \mathrm{m}^{2}\right)$ de híbrido de tilapia roja (Oreochromis mossambicus x Oreochromis niloticus) para formar tres tratamientos con tres réplicas. Los resultados del experimento de pre-engorda y engorda siguieron la misma tendencia. En ambos experimentos no encontramos dife-

\footnotetext{
*Autor para correspondencia:Wilfrido M. Contreras Sánchez Correo electrónico: contrerw@hotmail.com

rencias estadísticamente en el crecimiento de los camarones ni en las tilapias. Sin embargo, los bloques experimentales presentaron diferencias significativas $(P<0.05)$ en el peso promedio final. Los camarones de los bloques $B$ y $C$ fueron estadísticamente más grandes $(P<0.05)$ que los del bloque $A$. Para las dos etapas de crecimiento de los camarones, no se observó un efecto de la presencia de tilapias sobre la sobrevivencia o crecimiento de los camarones.

Palabras clave: policultivo tilapia-camarón, experimento de bloques al azar, peces y crustáceos.

\section{INTRODUCTION}

Disease outbreaks and price fluctuations continue to affect the stability of the shrimp industry in many parts of the world. The results from the survey of shrimp and tilapia farming (PD/A CRSP project polyculture) in Thailand, Philippines and Mexico showed that shrimp ponds are not being fully utilized in some areas, probably as a result of production problems. Surveys and experiments also support the idea that tilapia production, supplemented with low densities of shrimp, in shrimp ponds can provide an opportunity to develop a sustainable aquaculture system (Fitzsimmons, 2001). Tilapia production in former shrimp ponds (with and without shrimp) has increased rapidly in many locations including Thailand, the Philippines, Honduras, Peru and the desert of Arizona (Yi and Fitzsimmons, 2002; Bolivar et al., 2002; Wang and Lu, 2016). Aquaculture production of shrimp in Mexico has developed rapidly from 33,480 tons in 2000 to 127,814 tons in 2016 (FAO, 2018), having the majority of the shrimp farming industry located in the North West of Mexico (SAGARPA CONAPESCA, 2014).

Shrimp production procedures in farms are changing rapidly to deal with disease outbreaks and low yields (Roque and Goméz-Gil, 2000). Many farms have reduced stocking densities and the number of cycles of shrimp production per year. These changes have allowed farms to avoid environmental conditions of high disease risk and give the possibility of producing larger shrimp, which command better

Volumen XXII, Número 2 
prices in the shrimp markets. Several studies have addressed polyculture techniques to increase productivity in aquaculture systems. Polyculture systems, also called multi-trophic systems, relies on the cultivation of two or more species that differ in feeding behavior, habits and ecological requirements, to increase production in the same production unit (Zimmermann and New, 2000). Some authors suggest that tilapia is one of the most promising species in polyculture either in combination with other species of fish, or crustaceans (Wang and Lu, 2016). In a polyculture setting, tilapia and shrimp utilize different niches in the culture setting. In an extensive farm, tilapia can filter feed on phytoplankton and zooplankton in the upper water column, while shrimp spend most of the time in pond bottom grazing on bacterial films on the substrate and the detritus settling from above (Wang and Lu, 2016). This detrital matter consists of dying algae cells and fecal matter from tilapia. In a more intensive farm receiving pelleted feeds, tilapia monopolize the feed, especially if it is a floating feed. However, some feed particles will probably be available to the shrimp at the bottom of the pond. More importantly, fecal matter from the tilapia contributes to the detrital rain that supports the shrimp. Anggawa (1999) reported that yields of shrimp increased when all-male tilapia were stocked into existing shrimp ponds. In a study including Macrobrachium-tilapia polyculture, it was found that the yield of prawns was reduced if compared to monoculture, but increased total harvest of both fish and prawns (Garcia-Pérez et al., 2000). A report of a similar effect was in a tilapia-shrimp polyculture using brackish water (Yap, 2001).

From the disease aspect, tilapia seem to provide advantages in several ways. Farmers in Ecuador have reported that tilapia will consume dead or dying shrimp in polyculture ponds, supporting the idea that cannibalism is one of the primary vectors for transmission of shrimp diseases. Therefore, tilapia (which do not appear to be susceptible or carrier of these viruses), disrupt cannibalism as a mode of transmission. Tilapia also consume small crustaceans in shrimp ponds; these crustaceans are of concern as potential vectors (Watanabe et al., 2002). Having tilapia directly in the ponds or alternating with shrimp in a crop rotation can be useful for reducing crustacean populations. Bacterial infections also may be impacted by polyculture. Vibrio and most other bacterial pathogens common in shrimp culture are gram-negative while waters which have been used for fish culture tend to be predominated by gram-positive bacteria (Watanabe et al., 2002). Using water from a fish culture pond seems to reduce the prevalence of luminous Vibrio bacterial infections in shrimp ponds (Yap, 2001). Farmers in Asia and South America have provided anecdotal reports that shrimp production increases due to higher survival in some of these polyculture systems, however, carefully controlled and replicated trials are needed to study these systems better and confirm the results (Watanabe et al., 2002). In the present study, we evaluated the impact of low stocking densities of tilapia in a traditional setting for shrimp culture.

\section{MATERIAL AND METHODS}

We conducted two experimental settings to evaluate the results of polyculture between shrimp and tilapia. The first one evaluated the effects of stocking tilapia with shrimp during pre-growth and the second one during grow-out phase.

\section{Experimental organisms}

Shrimp (Litopenaeus vannamei) were purchased from "Grupo Pecis" laboratory and air freighted from Yucatan. They were at developmental stage PL12, and the supplier tested and certified that the shrimp were free from white spot syndrome virus (WSSV). At arrival, postlarvae were distributed in four cylindroconical 600L fiberglass tanks with constant aeration. Postlarvae were fed daily using Api-Camarón, Malta Cleyton $^{\mathrm{TM}}$ shrimp feed (proximate composition: $45 \%$ protein, $9 \%$ lipid, 3\% fiber, and 13\% ash), at 15\% body weight daily, distributed three times per day. Tilapias used were sex-reversed male red hybrids ( 0 . mossambicus $\times 0$. niloticus). Juveniles were brought from Jala, Colima, Mexico to the facilities of the CIAD-Mazatlán. To acclimatize tilapias to full strength seawater (35ppt) we raised salinity of the holding water daily by 5 ppt over seven days. After acclimatization, tilapias were maintained, until the starting date of the experiment, in six $400 \mathrm{~L}$ tanks with 24-hour aeration, 50\% water exchange every three days. Tilapias feeding was daily to apparent satiation with Silver Cup $^{\mathrm{TM}}$ tilapia feed (proximate composition: $45 \%$ protein, $16 \%$ lipid, $2.5 \%$ fiber, and $12 \%$ ash).

\section{Experimental pond and preparation}

The pond used was a conventional earth pond $(150 \mathrm{~m}$ $x 30 \mathrm{~m}$ ) with a light loam soil with low permeability, situated on a farm built by the edge of an estuary. Water was supplied to the pond by gravity from a reservoir canal, filled from the estuary with a large bore axle pump run by a diesel engine. Before usage, the pond was dried over two months, the earth bottom tilled using a conventional tractor and plow, and the bottom was limed. The water inlet is located at one end of the pond and the outlet at the other end. The middle portion of the pond with a depth of approximately $1 \mathrm{~m}$ was set up with nine experimental enclosures. Each enclosure measured $7 \mathrm{~m} \times 30 \mathrm{~m},\left(210 \mathrm{~m}^{2}\right)$. Divisions of $1 \mathrm{~mm}$ mosquito mesh, supported with a wooden stack every $3 \mathrm{~m}$, were set up across the pond to form the enclosures. These enclosures, numbered from one to nine from the inlet of the pond to the outlet, were divided into three blocks based on water flow, enclosures one to three formed block $A$ (first use water), four to six block $B$ (second use water), and seven to nine block $C$ (third use water) (Fig. 1).

\section{Experimental design}

In the two experiments, we used a completely randomized block design with three experimental treatments: zero tilapia with 30 shrimp per $\mathrm{m}^{2}$ (T0); 0.25 tilapia with 30 shrimp per $\mathrm{m}^{2}$ (T0.25); and 0.50 tilapia with 30 shrimp per $\mathrm{m}^{2}$ (T0.50). Each treatment was randomly placed into one of the three 


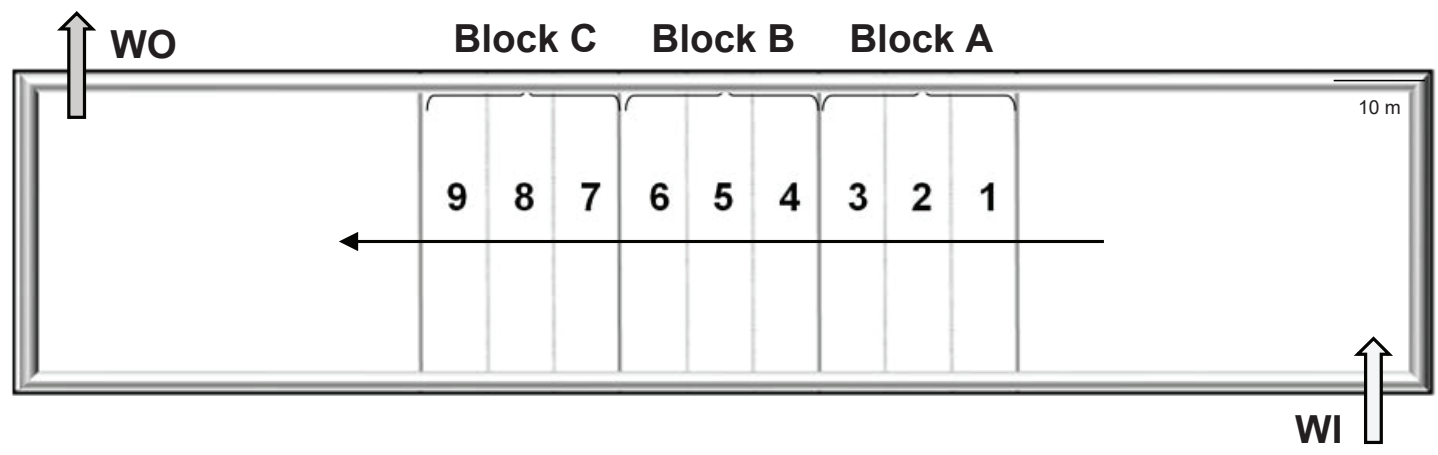

PRE GROWTH EXPERIMENT

\begin{tabular}{cc}
\hline TREATMENT & ENCLOSURES \\
\hline TO & 1,5 and 8 \\
\hline T0.25 & 3,4 , and 9 \\
\hline T0.50 & 2,6 and 7
\end{tabular}

GROWTH EXPERIMENT

\begin{tabular}{cc}
\hline TREATMENT & ENCLOSURES \\
\hline TO & 2,4 and 9 \\
\hline T0.25 & 3,6 , and 8 \\
\hline T0.50 & 1,5 and 7 \\
\hline
\end{tabular}

Figure 1. Experimental setting in a Shrimp pond where two completely randomized block experiments were conducted. The pond $(150 \times 30 \mathrm{~m})$ was conditioned with 9 enclosures (1-9) separated with mosquito mesh divisions. Arrows indicate water flow, Water Inlet (WI) and water outlet (WO). The Blocks considered for the experimental design are designated as A, B and C. Treatments are $\mathrm{T} 0=$ zero tilapia with 30 shrimp $/ \mathrm{m}^{2} ; \mathrm{T} 0.25=0.25$ tilapias with 30 shrimp $/ \mathrm{m}^{2}(\mathrm{~T} 0.25) ;$ and $\mathrm{T} 0.50=0.50$ tilapias with 30 shrimp $/ \mathrm{m}^{2}$.

enclosures in each block to provide three replicates for each treatment.

\section{Experiment 1: Pre-growth stocking}

After eight days of acclimation, we transported shrimp (PL 20) in plastic bags to the farm (1.5 hours). The bags with postlarvae were placed in the pond to bring water temperature to ambient values. Shrimp were randomly stocked into each enclosure by weight to give a stocking density of 30 shrimp per $\mathrm{m}^{2}$ in each enclosure (6,300 each). One day after shrimp stocking, we selected juvenile tilapias of similar size. A random sample of 30 tilapias was individually weighed to the nearest $0.1 \mathrm{~g}$ using an electronic balance (Scout, Ohaus Corp., Florham Park, NJ, USA). The fork length was measured to the nearest $1.0 \mathrm{~mm}$ using a digital Vernier Caliper then transported to the farm (1.5-hour journey time) in plastic bags containing oxygenated water. After acclimation, tilapias were randomly distributed into the six enclosures assigned with fish to give the appropriate stocking densities of 0.25 tilapia per $\mathrm{m}^{2}$, or 0.50 tilapia per $\mathrm{m}^{2}$. Initial weight for shrimp was $0.004 \mathrm{~g}( \pm 0.001)$, while tilapias had an average weight of $4.63 \mathrm{~g}( \pm 0.92)$.

\section{Experiment 2: Grow-out stocking}

The experimental design was similar to the previous one, changing the size of shrimp $(0.24 \mathrm{~g} \pm 0.01)$ and tilapias $(50.22 \mathrm{~g} \pm 0.82)$ used. Treatments were randomly assigned to blocks.

\section{Operation}

At the farm, no aeration was available for the experimental pond. At regular intervals, the water pump was operated to fill the reservoir before sunset; the pond was then left with a flow-through of water to renew the water during the night. Temperature, dissolved oxygen, and salinity were monitored daily. Dissolved oxygen was measured before dawn with an YSI Model 55 oxygen meter (Yellow Springs, $\mathrm{OH}, \mathrm{USA}$ ), and temperature with a digital thermometer (YSI 55, Yellow Springs OH, USA). The salinity was measured using a hand refractometer (Bio-marine Aquafauna, Hawthorne CA, USA). Ammonia, nitrite, and nitrate concentrations were measured with a multiparameter meter (Hanna Instruments, HI 98311, Woonsocket, RI, USA) once a week. The tilapia were fed Silver Cup ${ }^{\mathrm{TM}}$ tilapia feed (proximate composition: $45 \%$ protein, $16 \%$ lipid, $2.5 \%$ fiber, and $12 \%$ ash) at $10 \%$ body weight daily, distributed three times per day (7:00, 13:00 and 18:00 hours). The shrimp were fed 30 minutes later, using Api-Malta Cleyton ${ }^{\mathrm{TM}}$ shrimp feed (proximate composition: $45 \%$ protein, $9 \%$ lipid, 3\% fiber, and 13\% ash), at 10\% body weight daily, distributed three times per day.

\section{Growth sampling}

Samplings were conducted every two weeks in both experiments. Fish and shrimp were captured using a fine mesh cast net and measured. A total of 30 shrimp and 20 tilapias were weighed to the nearest $0.1 \mathrm{~g}$ in each enclosure. All organisms were lightly dried using paper towels before weighed. In the case of tilapias, the fork length was also mea- 
sured to the nearest $0.1 \mathrm{~mm}$. After eight weeks (experiment 1) and ten weeks (experiment 2), the pond was drained, and all shrimp and tilapia were caught and counted.

\section{Statistical analysis}

The effects of stocking different tilapia densities on shrimp growth were determined using a multifactor ANOVA for repeated measures. Block and treatment effects were evaluated on shrimp and tilapia growth (Kuehl, 2000). Survival percentages were arcsine-transformed before the ANOVA comparison, but reported and graphed as percentages. All statistical analyses were performed using the software Statgraphics Centurion ${ }^{T M} v 18$, with a significance level of $a<0.05$. All means are expressed as \pm one standard deviation.

\section{RESULTS}

Results from shrimp pre-growth and grow-out phases indicate that the polyculture with tilapia does not affect shrimp growth nor survival. Tilapias also grow well allowing the harvest of two species in the same aquaculture system. In general, water quality was good, with temperature, dissolved oxygen, and $\mathrm{pH}$ values favorable for shrimp culture (table 1). However, during the grow-out experiment, dissolved oxygen was below $3.00 \mathrm{~g} / \mathrm{L}$ and nitrates above $50 \mathrm{mg} / \mathrm{L}$. Ammonia and nitrates were higher in block $C$, while dissolved oxygen was slightly lower, indicating organic matter accumulation in this section of the pond. The grow-out experiment was stopped due to a progressive increase in salinity.

\section{Pre-growth phase}

Shrimp growth was similar in the absence or presence of tilapia. Results from the multifactor ANOVA for repeated measurements indicated highly significant differences in shrimp weight between sampling times $(p<0.001)$. However, no significant differences in shrimps weight were detected between treatments ( $p>0.05)$. After four weeks of experimentation, the mean weights $( \pm S D)$ from the replicas of the three treatments ranged from $0.68 \mathrm{~g}( \pm 0.09)$ to $0.72 \mathrm{~g}$ $( \pm 0.29)$. At the end of the experiment, the mean weights of the shrimp ranged from $2.05 \mathrm{~g}( \pm 0.48)$ to $2.19 \mathrm{~g}( \pm 0.56)$ (Fig. 2a). A significant block effect through time was indicated by the ANOVA test $(\mathrm{P}<0.05)$. The interaction between these two
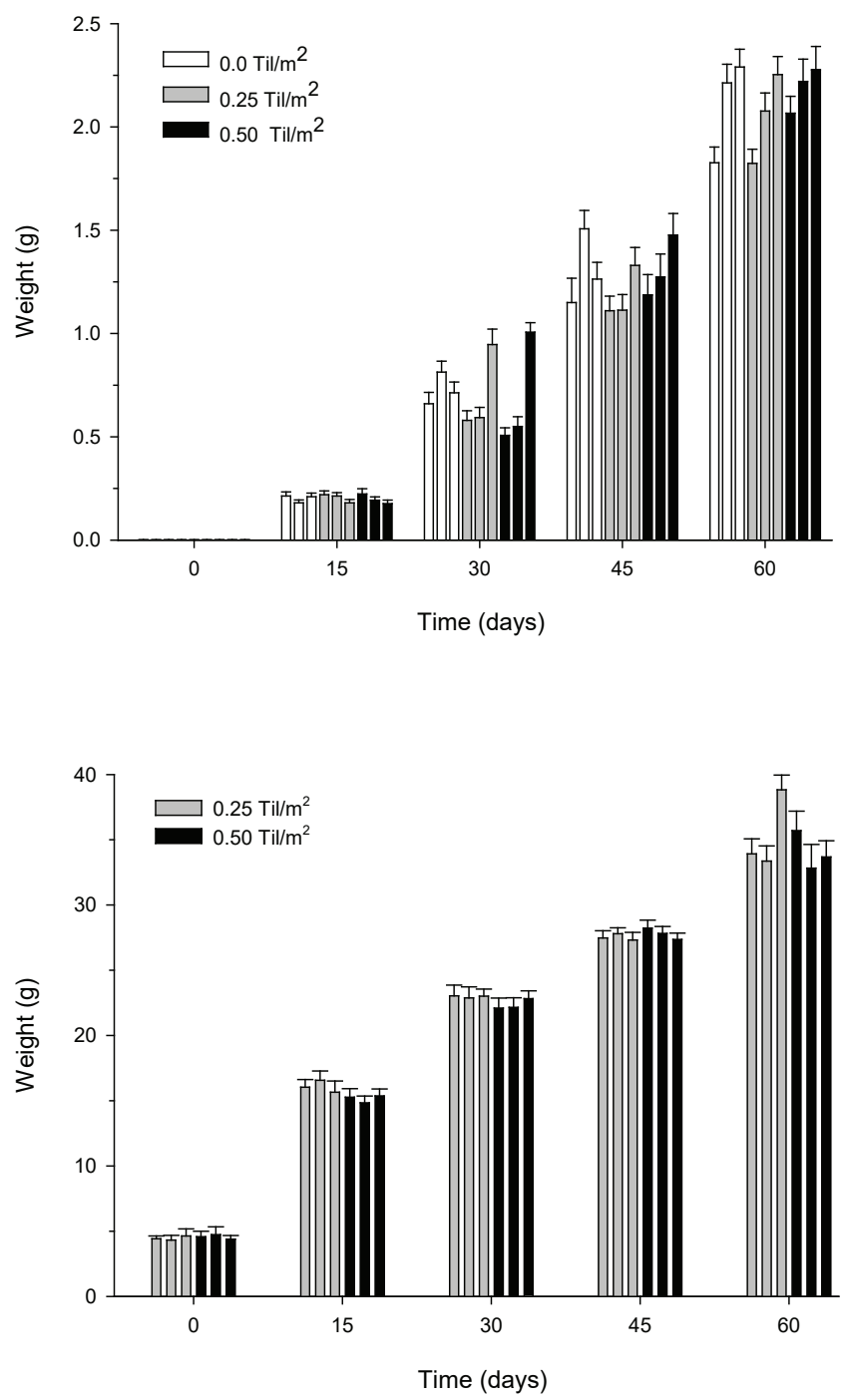

Figure 2. Mean weight $( \pm$ SE) of shrimp (A) and tilapia (B) over time during the pre-growth experiment. Each bar represents a replicate in a particular experiment the replicas are arranged from the lowest numbered enclosure on the left to highest on the right (block A to block C). Statistical differences $(p<0.001)$ were found between each sampling time; however, there were no differences between treatments. Sample size in each replicate was 30 for shrimp and 20 for tilapia.

Table 1. Mean values $( \pm S D)$ for water quality parameters during the pre-growth and grow-out experiments. Information is provided by block. DO = Dissolved Oxygen.

\begin{tabular}{|c|c|c|c|c|c|c|c|c|}
\hline \multirow[b]{2}{*}{ Experiment } & \multicolumn{8}{|c|}{ WATER QUALITY } \\
\hline & Block & $\begin{array}{c}\text { Temperature } \\
\text { (oC) }\end{array}$ & $\begin{array}{c}\mathrm{DO} \\
(\mathrm{mg} / \mathrm{L})\end{array}$ & $\begin{array}{l}\text { pH } \\
\text { (IU) }\end{array}$ & $\begin{array}{c}\text { Ammonia } \\
(\mathrm{mg} / \mathrm{L})\end{array}$ & $\begin{array}{l}\text { Nitrate } \\
\text { (mg/L) }\end{array}$ & $\begin{array}{l}\text { Nitrite } \\
\text { (mg/L) }\end{array}$ & $\begin{array}{l}\text { Salinity } \\
\text { (ppm) }\end{array}$ \\
\hline \multirow{3}{*}{ Pre-growth } & A & $13.58 \pm 0.75$ & $3.98 \pm 0.45$ & $6.90 \pm 0.67$ & $0.02 \pm 0.03$ & $47.67 \pm 5.69$ & $0.60 \pm 0.08$ & $29.33 \pm 1.05$ \\
\hline & B & $13.59 \pm 0.67$ & $3.92 \pm 0.41$ & $6.83 \pm 0.68$ & $0.02 \pm 0.03$ & $46.76 \pm 4.92$ & $0.58 \pm 0.06$ & $29.17 \pm 0.78$ \\
\hline & C & $13.55 \pm 0.68$ & $3.87 \pm 0.36$ & $6.76 \pm 0.83$ & $0.02 \pm 0.02$ & $46.33 \pm 3.92$ & $0.58 \pm 0.06$ & $29.10 \pm 0.84$ \\
\hline \multirow{3}{*}{ Grow-out } & A & $30.01 \pm 0.80$ & $3.00 \pm 0.31$ & $8.05 \pm 0.44$ & $0.04 \pm 0.02$ & $51.56 \pm 8.09$ & $0.70 \pm 0.12$ & $46.42 \pm 7.44$ \\
\hline & B & $30.73 \pm 2.91$ & $2.91 \pm 0.33$ & $7.92 \pm 0.41$ & $0.03 \pm 0.11$ & $57.03 \pm 15.69$ & $0.80 \pm 0.13$ & $52.18 \pm 9.89$ \\
\hline & C & $31.48 \pm 0.57$ & $2.82 \pm 0.40$ & $8.03 \pm 0.43$ & $0.11 \pm 0.18$ & $74.13 \pm 8.93$ & $0.80 \pm 0.15$ & $46.70 \pm 5.01$ \\
\hline
\end{tabular}


factors; shows that the shrimp in block $C$ grew significantly better than shrimp in block $A$; while shrimp in block $B$ had no differences with either $A$ or $C$ block (Fig. 3). At the end of the experiment, the shrimp in blocks $C(2.27 \mathrm{~g} \pm 0.53)$ and $B$ $(2.17 \mathrm{~g} \pm 0.52)$ were significantly bigger $(P<0.05)$ than shrimp in block $A(1.91 \mathrm{~g} \pm 0.43)$.

The tilapia growth was steady, showing a statistically significant increase at each sampling time $(p<0.001)$. However, growth was similar in both treatments containing fish, showing no statistical differences (ANOVA, $p>0.05$ ) on any sampling date. After eight weeks of growth, the mean weights from treatments ranged from $34.07 \mathrm{~g}( \pm 6.87)$ in T0.25 to $35.37 \mathrm{~g}( \pm 7.46)$ in T0.50 (Fig 2b). Overall, during the 60 days, the tilapias grew approximately $30.1 \mathrm{~g}$. At the end of the experiment, gonadal development of the tilapia was examined, the percentage of mature female tilapia in the enclosures ranged from 23 to $42 \%$.

Table 3a present the estimated values for yield, FCR, and SGR for shrimps and tilapias. These values reflect the observed weight in the experiment. In the treatments, average

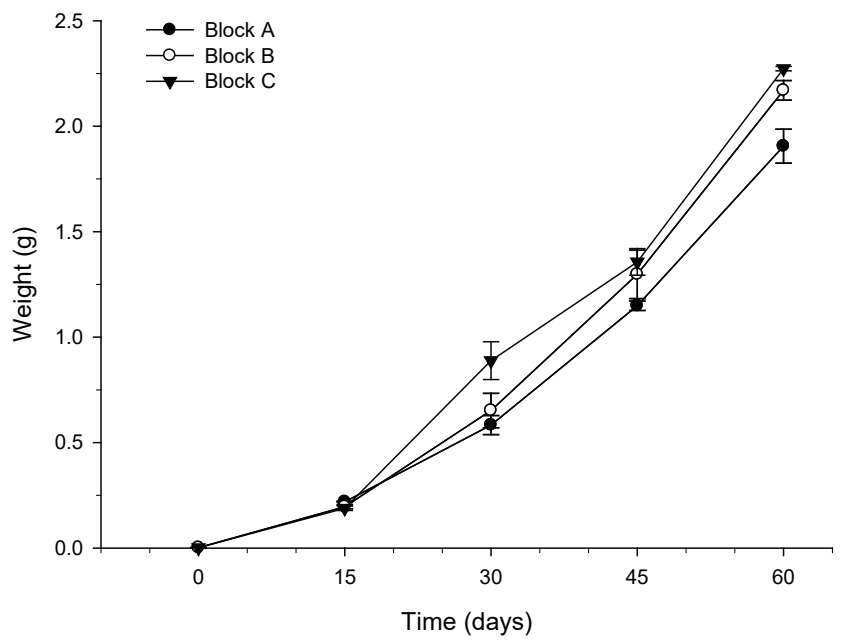

Figure 3. Block effect in the growth of shrimp (mean weight $\pm \mathrm{SE}$ ) over time during the pre-growth experiment. Different letters indicate statistically significant differences $(p<0.05)$ between blocks at each particular time. Highly significant differences $(p<0.001)$ were also observed between sampling times. Sample size for each block was $n=90$. yield of shrimp ranged from 7.23 to $7.68 \mathrm{Kg}$ of shrimp, reaching a SGR from 0.03 to $0.04 \mathrm{~g} /$ day. Shrimp yield in blocks progressively augmented from 5.97 to 6.61 and $9.72 \mathrm{Kg}$ per enclosure. FCR was high for shrimps and tilapias (2.11 to 2.45 for shrimp and 3.13 to 3.14 for tilapias).

\section{Grow-out phase}

Once again, the results indicate that the growth of the shrimp was similar in the absence or presence of tilapia (Fig. 4a). The effects detected by the multifactor ANOVA for repeated measures on shrimp growth where only between sampling times $(p<0.001)$, while no significant differences were detected between treatments $(p>0.05)$. A significant effect of the interaction between blocks and time $(p<0.01)$ is explained by better growth in block $C$ after 30 days of experimentation. At the end of the experiment, the shrimps in block $C(8.68 \mathrm{~g} \pm 0.31)$ were significantly bigger $(P<0.05)$ than shrimp in block $A(8.06 g \pm 0.23)$ and $B(7.75 g \pm 0.27)$ (Fig. 5). The growth of the tilapia was continuous, with statistically significant increases $(p<0.001)$ at each sampling time (Fig. 4b). No significant differences between treatments were found on any sampling date (ANOVA, $p>0.05$ ). At the end of the experiment, tilapia weight ranged between 114.95 and $117.01 \mathrm{~g}$.

Table $3 \mathrm{~b}$ shows estimated values for yield, FCR, and SGR for shrimps and tilapias during the grow-out phase. In the treatments, average yield of shrimp ranged from 30.48 to $32.64 \mathrm{Kg}$ of shrimp per enclosure, reaching a SGR from 0.10 to $0.11 \mathrm{~g} /$ day. Shrimp yield in blocks increased from $29.1 \mathrm{Kg}$ per enclosure in blocks $\mathrm{A}$ and $\mathrm{B}$, and $33.34 \mathrm{Kg}$ per enclosure in block C. Again, FCR was high for shrimps and tilapias (3.05 to 3.28 for shrimp and 4.86 to 5.48 for tilapias).

\section{Survival}

Shrimp and tilapias had similar percent survival in both experiments. No significant effects were observed at the block or treatment level ( $p>0.05)$. During the pregrowth stage, shrimp survival ranged from $56.47 \%$ to 59.28 $\%$ while during the grow-out stage, fish reached from 63.57 $\%$ to $65.68 \%$. Survival of the tilapias in the two experiments was high, ranging from $76.67 \%$ to $90.67 \%$ (Table 1).

Table 2. Mean percent survival $( \pm S D$ ) of $L$. vannamei and O. niloticus during the pre-growth and grow-out experiments. No significant differences (ANOVA; $P$ $>0.05$ ) observed between treatments (TREAT) or blocks.

\begin{tabular}{|c|c|c|c|c|c|c|c|c|}
\hline \multirow[b]{2}{*}{ Species } & \multicolumn{4}{|c|}{ PRE-GROWTH } & \multicolumn{4}{|c|}{ GROW-OUT } \\
\hline & TREAT & $\begin{array}{c}\text { WEIGHT MEAN } \\
( \pm \text { SD })\end{array}$ & BLOCK & MEAN ( \pm SD) & TREAT & MEAN ( \pm SD) & BLOCK & MEAN ( \pm SD) \\
\hline \multirow{3}{*}{ Shrimp } & TO & $56.47 \pm 15.11$ & A & $52.06 \pm 4.30$ & T0 & $65.68 \pm 12.55$ & $A$ & $60.91 \pm 11.97$ \\
\hline & T0.25 & $59.28 \pm 12.52$ & B & $50.86 \pm 3.79$ & T0.25 & $63.57 \pm 9.99$ & B & $62.89 \pm 6.78$ \\
\hline & T0.50 & $58.44 \pm 7.31$ & C & $71.28 \pm 4.24$ & T0.50 & $63.97 \pm 12.38$ & C & $69.43 \pm 12.86$ \\
\hline \multirow{3}{*}{ Tilapia } & T0 & - & A & $89.00 \pm 4.24$ & T0 & - & A & $69.50 \pm 0.71$ \\
\hline & T0.25 & $89.33 \pm 3.06$ & B & $91.50 \pm 0.71$ & T0.25 & $76.67 \pm 6.11$ & B & $72.50 \pm 7.78$ \\
\hline & T0.50 & $90.67 \pm 1.53$ & C & $89.50 \pm 0.71$ & T0.50 & $69.33 \pm 2.52$ & C & $77.00 \pm 7.07$ \\
\hline
\end{tabular}


Table 3. Mean production values $( \pm$ SD) obtained by treatment (TREAT) and blocks for shrimp and tilapia during the pre-growth (a) and grow-out (b) experiments. No significant differences (ANOVA; P $>0.05$ ) were observed for treatment or blocks. FCR $=$ Feed Conversion Ratio; SGR = Specific Growth Rate.

\begin{tabular}{|c|c|c|c|c|c|c|c|c|}
\hline \multirow[b]{2}{*}{ Species } & \multirow[b]{2}{*}{ TREAT } & \multirow[b]{2}{*}{ YIELD (Kg) } & \multicolumn{3}{|c|}{ a) PRE-GROWTH } & \multirow[b]{2}{*}{ YIELD (kg) } & \multirow[b]{2}{*}{ FCR } & \multirow[b]{2}{*}{ SGR } \\
\hline & & & FCR & SGR (g/day) & BLOCK & & & \\
\hline \multirow{3}{*}{ Shrimp } & 0 & $7.23 \pm 2.56$ & $2.45 \pm 0.75$ & $0.04 \pm 0.004$ & A & $5.97 \pm 0.94$ & $2.46 \pm 0.40$ & $0.03 \pm 0.002$ \\
\hline & 0.25 & $7.39 \pm 2.29$ & $2.17 \pm 0.38$ & $0.03 \pm 0.004$ & B & $6.61 \pm 0.38$ & $2.41 \pm 0.48$ & $0.04 \pm 0.004$ \\
\hline & 0.50 & $7.68 \pm 1.19$ & $2.11 \pm 0.08$ & $0.04 \pm 0.002$ & $\mathrm{C}$ & $9.72 \pm 0.57$ & $1.85 \pm 0.28$ & $0.04 \pm 0.002$ \\
\hline \multirow{3}{*}{ Tilapia } & 0 & - & - & - & A & $2.37 \pm 1.29$ & $3.16 \pm 0.30$ & $0.58 \pm 0.02$ \\
\hline & 0.25 & $1.58 \pm 0.15$ & $3.14 \pm 0.30$ & $0.51 \pm 0.05$ & B & $2.26 \pm 1.03$ & $3.22 \pm 0.16$ & $0.55 \pm 0.01$ \\
\hline & 0.50 & $3.09 \pm 0.17$ & $3.13 \pm 0.02$ & $0.49 \pm 0.02$ & C & $2.37 \pm 1.03$ & $3.02 \pm 0.16$ & $0.60 \pm 0.01$ \\
\hline
\end{tabular}

\begin{tabular}{|c|c|c|c|c|c|c|c|c|}
\hline \multicolumn{9}{|c|}{ b) GROW-OUT } \\
\hline Species & TREAT & YIELD (Kg) & FCR & SGR (g/day) & BLOCK & YIELD (kg) & FCR & SGR \\
\hline \multirow{3}{*}{ Shrimp } & 0.00 & $32.64 \pm 5.59$ & $3.05 \pm 0.23$ & $0.11 \pm 0.009$ & $A$ & $29.12 \pm 3.31$ & $3.05 \pm 0.23$ & $0.10 \pm 0.009$ \\
\hline & 0.25 & $30.48 \pm 2.88$ & $3.28 \pm 0.72$ & $0.10 \pm 0.016$ & B & $29.19 \pm 2.48$ & $3.28 \pm 0.72$ & $0.10 \pm 0.016$ \\
\hline & 0.50 & $30.53 \pm 5.05$ & $3.21 \pm 0.42$ & $0.10 \pm 0.004$ & C & $35.34 \pm 3.76$ & $3.21 \pm 0.42$ & $0.11 \pm 0.004$ \\
\hline \multirow{3}{*}{ Tilapia } & 0.00 & - & - & - & A & $6.11 \pm 2.92$ & $5.29 \pm 0.04$ & $0.89 \pm 0.028$ \\
\hline & 0.25 & $4.51 \pm 0.44$ & $4.86 \pm 0.39$ & $0.90 \pm 0.029$ & B & $6.06 \pm 2.09$ & $5.20 \pm 0.78$ & $0.86 \pm 0.046$ \\
\hline & 0.50 & $7.94 \pm 0.35$ & $5.48 \pm 0.24$ & $0.86 \pm 0.046$ & C & $6.51 \pm 2.25$ & $5.03 \pm 0.58$ & $0.88 \pm 0.069$ \\
\hline
\end{tabular}
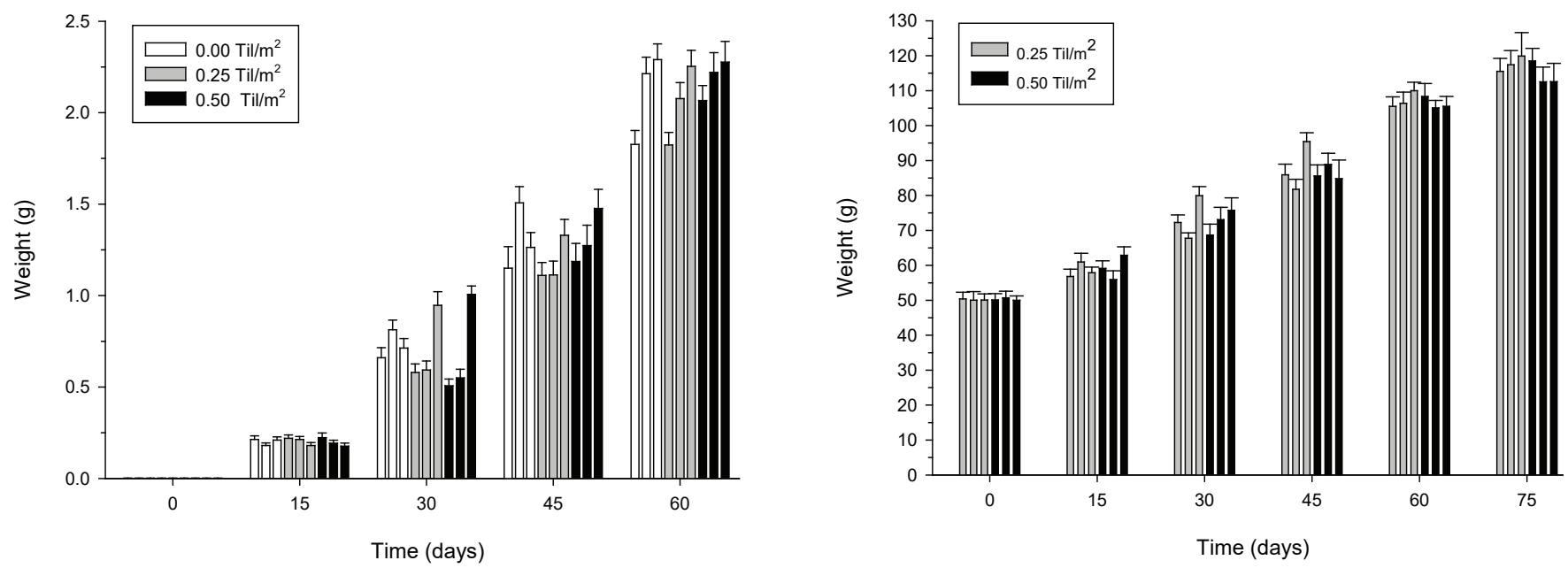

Figure 4. Mean weight ( \pm SE) of shrimp $(A)$ and tilapia $(B)$ over time during the grow-out experiment. Each bar represents a replicate in a particular experiment the replicas are arranged from the lowest numbered enclosure on the left to highest on the right (block $A$ to block $C$ ). Statistical differences ( $p<0.001$ ) were found between each sampling time; however, there were no differences between treatments. Sample size in each replicate was 30 for shrimp and 20 for tilapia.

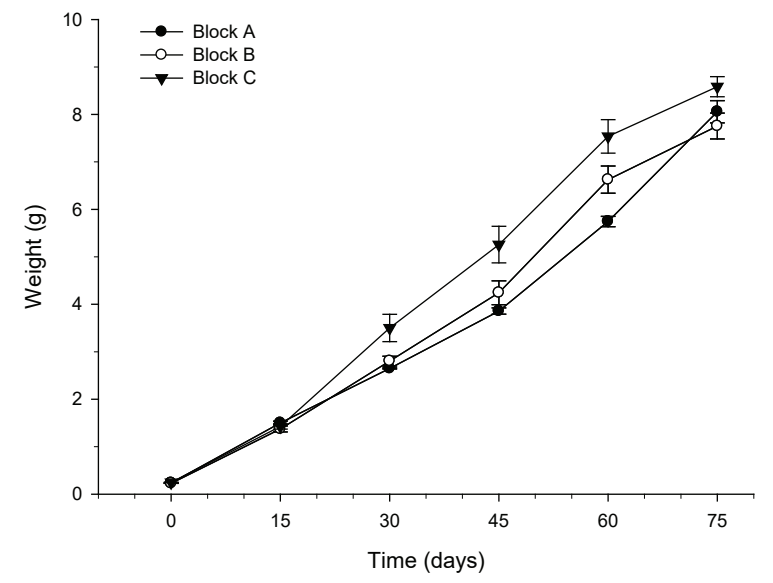

Figure 5. Block effect in the growth of shrimp (mean weight \pm SE) over time during the grow-out experiment. Different letters indicate statistically significant differences $(p<0.05)$ between blocks at each particular time. Highly significant differences $(p<0.001)$ were also observed between sampling times. Sample size for each block was $n=90$.

\section{DISCUSSION}

The results obtained in the present study confirm that the polyculture shrimp-tilapia is a viable alternative in the production of aquatic food under marine conditions. The evaluated stocking densities of tilapia did not affect the survival or growth of the shrimp. Based on these results, the direct benefits from these particular trials are related to increased profitability provided by the tilapia harvest.

The main support for shrimp-tilapia polyculture focusses on the beneficial impacts that tilapia may cause in the pond ecosystem. These benefits of polyculture with tilapia are summarized by Cruz et al. (2008) highlighting the promotion of blooms of desired phytoplankton species such as Chlorella, enhanced water quality, feeding on organic waste, and production of natural antimicrobials that potentially suppress Vibrio species growth. However, the information published addressing the benefits of shrimp production va- 
ries widely. Many researchers have presented supportive information indicating that shrimp production is enhanced or unaffected by the presence of tilapia (Gonzáles-Corre, 1988; Akiyama and Anggawati, 1999; Tian et al, 2001; Yap, 2001; Li and Dong, 2002; Yi et al., 2002; Massaut and Rodriguez, 2004, Hernández-Barraza et al., 2012; Bessa-Junior et al., 2012). On the other hand, some researchers have reported negative impacts of tilapia in shrimp or freshwater prawn production (Garcia-Perez et al., 2000; Simao et al., 2013).

Our results coincide with those found by $\mathrm{Yi}$ et al. (2002), and Massaut and Rodriguez (2004) who reported no impact on shrimp production when tilapias are used at low densities $\left(0.25\right.$ to $\left.1 \mathrm{fish} / \mathrm{m}^{2}\right)$. It is important to highlight that the study conducted by Yi et al. (2002) contained a similar setting to ours since both projects contemplated similar experiments in two distant regions with small variants (species used and salinity). Interestingly, both studies reached similar conclusions.

The highest tilapia density evaluated in our study $(0.5$ tilapia $/ \mathrm{m}^{2}$ ) during pre-growth or grow-out of shrimp did not affect shrimp productivity in these culture phases. In extensive monoculture conditions, tilapias are stocked at high densities (25 to $100 \mathrm{fish} / \mathrm{m}^{2}$; for juveniles) during pre-growth (Watanabe et al. 1997, Green and Engle, 2000) and one to eight tilapia/ $\mathrm{m}^{2}$ for grow-out (Lovshin, 2000; Popma and Rodriquez, 2000; Reyes and Ordonez, 2014). In polyculture, in contrast, tilapia densities are significantly lower $(0.25$ to eight/ $\mathrm{m}^{2}$ ) with shrimp densities ranging from three to 30 per $\mathrm{m}^{2}$ (Bessa-Junior et al., 2012; Simao et al., 2013; Fitzsimmons and Shahkar, 2017). However, the highest tilapia densities are placed in enclosures. Similar tilapia densities have been used in tilapia-prawn polyculture (New and Valenti, 2017). With our results, there is evidence for further evaluation of higher tilapia density for marine polyculture systems.

The average survival in our study $(60.4 \%)$ is satisfactory since this factor range between $30 \%$ and $80 \%$ (Sammy, 1988; Medley, 1991; Rouse et al., 1991). Once again, the fact that tilapias are freely foraging in the pond without affect shrimp survival is a good indicator for promoting this culture method. Moreover, some researchers argue that the effects of the tilapia presence in the pond are beneficial, reducing the incidence and severity of several bacterial and viral infections responsible for marine shrimp mortality (Fitzsimmons and Shahkar, 2017). However, as Wang and Lu (2016) proposed, the mechanism on how the presence of fish in the shrimp pond may control bacterial or viral shrimp diseases it is not fully understood and seems to be more complex than what we perceive.

Shrimp-tilapia polyculture has been evaluated in different modalities: simultaneous, sequential and rotational (Fitzsimmons and Shahkar, 2017). The simultaneous method implies that shrimp and tilapias coexist in ponds or enclosures, either freely or with tilapias confined in hapas or cages. In the sequential method, both species are produced in different ponds, and the water from the tilapia culture is pumped onto the shrimp pond. In the rotational procedure, tilapia production is conducted between shrimp cycles. Based on extensive reviews, simultaneous tilapia and shrimp stocking is the most common method used, where tilapias are placed in enclosures (Wang and Lu, 2016; Fitzsimmons and Shahkar, 2017). In Mexico, most shrimp farmers are reluctant to stock both species together, adducing that tilapia will predate on the shrimp. Our results should encourage shrimp farmers to take advantage of this method, obtaining the benefit of additional tilapia harvests.

The additional results obtained by the blocking effect in the experimental design show an adverse effect on shrimp survival and growth by the position of the enclosure in the pond. Shrimp survival and growth indicators were significantly higher with water that had previously passed through other enclosures. These results support the idea that tilapia disrupt the sediments and provides organic matter that is available to shrimp as food. Data from water quality indicates such concentrations of organic matter at the end of the pond. It is possible that these conditions provided some nutritional advantage as the used water might carry sediments and provide a better environment for bacterial growth that the shrimp could use as a nutritional source.

Despite promising results, shrimp polyculture has not been adopted as a common practice among shrimp farmers in Mexico. Martínez-Porchas et al. (2010) recognized that this activity represents an important alternative to solve or at least minimize some of the problems that shrimp aquaculture faces in the world, but for some reason, farmers look at it reluctantly.

\section{CONCLUSIONS}

In conclusion, this study demonstrated that under these culture conditions, juvenile shrimp growth and survival were not affected by the presence of tilapia and the production from the pond system was increased with the added tilapia production. Tilapia stocking density did not affect production, and it is possible that higher stocking densities of tilapia could be considered.

\section{ACKNOWLEDGMENTS}

We thank Juan Manuel Gonzalez and his family for their help and use of a pond and facilities on their shrimp farm and Gabriela Velasco, Rafael Guzman, Ricardo Alvares, Michael Achury and Noemi Garcia for technical help. This research is a component of the Aquaculture CRSP, supported in part by the US Agency for International Development (USAID) Grant No. LAG-G-00-96-90015-00. The opinions expressed herein are those of the authors and do not necessarily reflect the views of the Aquaculture CRSP or USAID. CONACyT provided a scholarship for Alejandro Mcdonal-Vera.

\section{REFERENCES}

Akiyama, D.M., Anggawati, A.M. 1999. Polyculture of shrimp and tilapia in East Java. American Soybean Association (ASA), Technical Bulletin AQ 47. 
Anggawa, A. 1999. Polyculture of shrimp and tilapia in east Java. American Soybean Association (ASA) Technical Bulletin AQ47.

Bessa-Junior, B., Paula, A., Azevedo, C.M.D.S.B., Henry-Silva, G.G. 2012. Polyculture of Nile tilapia and shrimp at different stocking densities. Rev Bras Zootecn. 41 (7): 1561-1569.

Bolivar, R.B., Sugue, J.R., Fitzsimmons, K. 2002. Survey of TilapiaShrimp Polyculture in the Philippines. Tenth Work Plan, New Aquaculture Systems/New Species Research 3E (10NSR3E). In: PD/A CRSP Twentieth Annual Administrative Report Research Projects. New Aquaculture Systems/New Species Research. Subcontract No. RD010E-11. Internet address: http://pdacrsp. oregonstate.edu/pubs/admin/20arhtml/ rp_nasnsr.html

Cruz, P.S., Andalecio, M.N., Bolivar, R.B., Fitzsimmons, K. 2008. Tilapia-shrimp polyculture in Negros Island, Philippines: a review. J World Aquacult Soc. 39 (6), 713-725.

FAO, Statistical Query Results. 2018. http://www.fao.org/ figis/servlet/SQServlet?file $=\quad$ /usr/local/tomcat/8.5.16/ figis/webapps/figis/temp/hqp_7062100451809649267. xml\&outtype=html. Consulted June 20, 2018.

Fitzsimmons, K. 2001. Polyculture of Tilapia and penaeid shrimp. GAA. 4 (3): 43-44.

Fitzsimmons, K.M., Shahkar, E. 2017. Tilapia-Shrimp Polyculture. In: Tilapia in Intensive Co-culture, First Edition. Edited by Peter W. Perschbacher and Robert R. Stickney. John Wiley \& Sons, Ltd. pp 94-113.

Garcia-Perez, A., Alston, D., Cortes-Maldonado, R. 2000. Growth, survival, yield and size distribution of freshwater prawn, Macrobrachium rossenbergii, and tilapia, Oreochromis niloticus, in polyculture and monoculture systems in Puerto Rico. J World Aquacult Soc. 31 (3): 446-451.

Gonzales-Corre, K. 1988. Polyculture of the tiger shrimp (Penaeus monodon) with the Nile tilapia (Oreochromis niloticus) in brackish water fish ponds. In: R.S.V. Pullin, T. Bhukaswan \& K. Tonguthai (eds.). Proceedings of the Second International Symposium on Tilapia in Aquaculture, Manila, pp. 15-20.

Green, B.E., Engle, C.R. 2000. Commercial Tilapia Aquaculture in Honduras. In: B. A. Costa-Pierce and J. E. Rakocy, eds. Tilapia Aquaculture in the Americas. Vol. 2. The World Aquaculture Society, Baton Rouge, Louisiana, U. S. pp: 151-170.

Hernández-Barraza, C. 2012. Evaluación del crecimiento de camarón blanco del pacifico (Litopenaeus vannamei) en policultivo con tilapia roja (Oreochromis mossambicus $\mathrm{x} O$. nilotica) bajo un sistema de recirculación de agua. CienciaUAT. 3: 41-45 pp.

Kuehl, R.O., Kuehl, R.O. 2000. Design of experiments: statistical principles of research design and analysis. Pacific Grove, C A: Duxbury/Thomson Learning, $686 \mathrm{pp}$.

Li, D., Dong S. 2002. Summary of studies on closed-polyculture of penaeid shrimp with tilapia and molluscans. Oceanol Et Limnol Sin. 33, 90-96.

Lovshin, L.L. 2000. Tilapia culture in Brazil. In: B. Costa-Pierce and E. Rakocy, eds. Tilapia Aquaculture in the Americas, Vol. 2. World Aquaculture Society. Baton, Rouge, Louisiana, U.S. pp: 119-132.

Martínez-Porchas, M., Martínez-Córdova, L.R., Porchas-Cornejo, M.A., López-Elías, J.A. 2010. Shrimp polyculture: a potentially profitable, sustainable, but uncommon aquacultural practice. Rev Aquacult. 2 (2), 73-85.

Massaut, L., Rodríguez, R. 2004. El efecto de la Tilapia sobre la producción de camarón bajo condiciones de mancha blanca. Comunicación Científica (CIVA) 706-712 pp.
Medley, P.B., Rouse, D.B., Brady, Y.J. 1993. Interaction and disease relationships between Australian red claw crayfish (Cherax quadricarinatus) and red swamp crayfish (Procambarus clarkii) in communal ponds. Freshw Crayfish. 9: 50-56.

New, M.B., Valenti, W.C. 2017. Tilapia-Macrobrachium Polyculture. In: Tilapia in Intensive Co-culture, First Edition. Edited by Peter W. Perschbacher and Robert R. Stickney. John Wiley \& Sons, Ltd. pp 156-185.

Popma, T.J., Rodríguez, B.F. 2000. Tilapia aquaculture in Colombia. In: B. Costa-Pierce and E. Rakocy, eds. Tilapia Aquaculture in the Americas, Vol. 2. World Aquaculture Society. Baton, Rouge, Louisiana, U.S. pp: 141-150.

Reyes, C.D., Ordoñez, M.J. 2014. Policultivo de camarón blanco (Litopenaeus vannamei) y tilapia roja (Oreochromis sp.) en agua salada en el sur de Honduras. Tesis licenciatura. Escuela Agrícola Panamericana, Zamorano Honduras. 25 pp.

Roque, A., Goméz-Gil, B. 2000. Estrategias y capacitación en el manejo sanitario de especies acuícolas. In: Memorias del III Simposium Internacional de Acuicultura AquaMexico 2000, Culiacán, México. 5-7 Octobre 2000. pp 245-253.

Rouse, D.B., Austin, C.M., Medley, P.M. 1991. Progress Toward Profits? Information on the Australian crayfish. Aquacult Mag. 17:46-56.

SAGARPA CONAPESCA. 2014. Anuario estadístico de pesca. Secretaria de agricultura, ganadería, desarrollo rural, pesca y alimentación. pp 306.

Simao, B.R., Brito, L.O., Maia, A.S.C., Miranda, L.C., Azevedo, C.M.D.S.B. 2013. Stocking densities and feeding strategies in shrimp and tilapia polyculture in tanks. Pesq Agropec Bras. 48, 1088-1095.

Tian, X., Li, D., Dong, S., Yan, X., Qi, Z., Liu, G., Lu, J. 2001. An experimental study on closed-polyculture of penaeid shrimp with tilapia and constricted tagelus. Aquaculture, $202(1-2), 57-71$.

Wang, M., Lu, M. 2016. Tilapia polyculture: a global review. Aqua res. 47 (8): 2363-2374.

Watanabe, W., Wicklund, R., Olla B., Head, W. 1997. Saltwater culture of the Florida red tilapia and other saline-tolerant tilapias: a Review. In: B. Costa-Pierce and E. Rakocy, eds. Tilapia Aquaculture in the Americas, Vol. 1. World Aquaculture Society. Baton, Rouge, Louisiana, U.S. pp: 54-141.

Watanabe, W.O., Losordo, T.M., Fitzsimmons, K., Hanley, F. 2002. Tilapia production systems in the Americas: technological advances, trends, and challenges. Rev in fish sci. 10 (3-4): 465-498.

Yap, W.G. 2001. The lowdown on world shrimp culture - II. INFOFISH International 2001(3): 20-27.

Yi, Y., Fitzsimmons, K. 2002. Survey of Tilapia-Shrimp Polycultures in Vietnam and Thailand. Final Report. Tenth Work Plan, New Aquaculture Systems/New Species Research 3A (10NSR3A). In: PD/A CRSP Twentieth Annual Administrative Report Research Projects. New Aquaculture Systems/New Species Research. Subcontract No. RD010E-11. Internet address: http://pdacrsp.oregonstate.edu/pubs/admin/20arhtml/ rp_nasnsr.html

Yi, Y., Saelee, W., Naditrom, P., Fitzsimmons, K. 2002. Stocking densities for tilapia-shrimp polyculture in Thailand. Twentieth Annual Technical Report, Pond Dynamics/ Aquaculture Collaborative Research Support Program, Oregon State University, Corvallis, Oregon.

Zimmermann S., New M.B. 2000. Grow-out systems polyculture and integrated culture. In M.B. New and W.C. Valenti eds. Freshwater Prawn Culture. Blackwell Science, Oxford, U K. pp: 187-202. 